\title{
Comorbidity and confounding factors in attention-deficit/hyperactivity disorder and sleep disorders in children
}

This article was published in the following Dove Press journal:

Psychology Research and Behavior Management

26 September 201I

Number of times this article has been viewed

Ya-Wen Jan ${ }^{1,2}$

Chien-Ming Yang 1,3

Yu-Shu Huang ${ }^{4,5}$

'Department of Psychology, National Cheng-Chi University, Taipei; ${ }^{2}$ Sleep

Center of Taipei Medical University Hospital, Taipei; ${ }^{3}$ The Research

Center for Mind Brain and Learning, National Cheng-Chi University, Taipei; ${ }^{4}$ Department of Child Psychiatry and Sleep Center, Chang Gung Memorial Hospital, Taoyuan; ${ }^{5}$ College of Medicine, Chang Gung University, Taoyuan, Taiwan
Correspondence: Yu-Shu Huang Department of Child Psychiatry and Sleep Center, Chang Gung Memorial Hospital, Linkou,

Taiwan No 5, Fu-Shing Street,

Kwei-Shan, Taoyuan 333,

Taipei, Taiwan

$\mathrm{Tel}+8863328$ I 200 ext $854 \mid$

Fax +88633184541

Email hulI09s@yahoo.com.tw
Abstract: Sleep problems are commonly reported in children with attention-deficit/hyperactivity disorder (ADHD) symptoms. Research data regarding the complex and reciprocal relationship between ADHD and sleep disturbances has now accumulated. This paper is focused on the types of sleep problems that are associated with ADHD symptomatology, and attempts to untangle confounding factors and overlapping symptoms. The goal is also to present an updated overview of the pathophysiology of and treatment strategies for sleep problems in children with ADHD. The review also points out that future research will be needed to clarify further the other psychiatric comorbidities and side effects of medication in order to improve treatment outcomes and prevent misdiagnosis in clinical practice.

Keywords: attention-deficit/hyperactivity disorder, sleep, children

\section{Introduction}

Attention-deficit/hyperactivity disorder (ADHD) is one of the most commonly studied and diagnosed psychiatric disorders in children, and is characterized by inattention, overactivity, and impulsivity. ${ }^{1}$ ADHD is estimated to affect about $3 \%-5 \%$ of children globally, ${ }^{2}$ although prevalence rates may vary depending on whether samples are obtained from community or clinical settings. ${ }^{3,4}$ Complaints of sleep problems in children with ADHD are not uncommon. In 1957, Laufer and Denhoff ${ }^{5}$ first reported the association between sleep disturbances and ADHD. They noted "Generally, the parents of hyperkinetic children are so desperate over the night problems that the daytime ones pale in significance". Restless and disturbed sleep were, at one time, part of the Diagnostic and Statistical Manual of Mental Disorders (DSM) diagnostic criteria for ADHD, although the symptoms were eliminated from subsequent DSM editions. ${ }^{1,6,7}$ In recent years, there has been growing interest in sleep disorders associated with ADHD. Manifestations of primary sleep disorders may mimic ADHD symptomatology, so might lead to misdiagnosis in clinical practice. Moreover, the primary sleep disorders may exacerbate underlying ADHD symptoms, which might interfere with the treatment and impair daytime performance. In addition, psychotropic medications that are used to treat ADHD may also result in sleep problems, such as sleep initiation difficulty. Therefore, the management of sleep problems in children with ADHD may significantly reduce behavioral symptom severity and improve the quality of life of these children, as well as that of their families. ${ }^{8}$

However, variations in the inclusion criteria and measurements across the studies have impeded our understanding of the ways in which sleep and ADHD interact. This 
review attempts to clarify the potential confounding factors of previous research regarding the relationships between sleep problems and ADHD in children, and outlines some treatment considerations in the management of sleep disturbances in ADHD. We performed a PubMed search from 1994 (when the American Psychiatric Association first published the DSM-IV) to May 2011, using the following key words in various combinations: "ADHD”, "attention-deficit/hyperactivity disorder", "sleep", sleep disorder", and "children". References from each relevant paper, including 14 existing reviews of the literature, were examined to determine if any relevant studies had been missed during the database searches. Case reports and descriptive reports without data analysis were excluded in our review.

\section{Diagnosis and comorbidity in ADHD}

Some of the published studies have reported that the prevalence of sleep disturbances and sleep disorders among children with ADHD are significantly higher than in normal controls, but others failed to replicate these findings. ${ }^{9,10}$ One possible reason for the inconsistent results may be that the methods used to define ADHD differed across studies, ranging from subjective rating scales for symptoms of hyperactivity/ impulsivity and inattention to clinical judgments made by experienced physicians who were following DSM diagnostic criteria. The studies in which ADHD was defined by questionnaires might be confounded by factors such as psychiatric comorbidity. ${ }^{11}$ Many studies that applied DSM diagnostic criteria did not exclude or control the effects of psychiatric comorbidity as well. Comorbid disorders frequently associated with ADHD, such as tic disorder, ${ }^{12}$ oppositional defiant disorder, ${ }^{9}$ depressive disorders, ${ }^{13}$ and anxiety disorders, ${ }^{13-15}$ may account for some of the sleep disturbances.

\section{Subjective and objective measures of sleep in ADHD children}

Subjective reports of sleep in children with ADHD have primarily been collected through parental-report questionnaires and sleep logs. The data collected usually include: sleep quality and quantity, with variables (Table 1) such as difficulty in sleep initiation and/or sleep onset latency, total sleep time, wake after sleep onset, number of night-time awakenings, and sleep efficiency; sleep habits and bedtime behaviors, like sleep resistance; and symptoms of sleep disorders, including sleep-related breathing disorders and movement disorders. However, the reliability and validity of subjective sleep measurement may be questionable. It has been reported that the sleep data assessed by the Child Behavior Checklist, a
Table I Definition of the sleep parameters

\begin{tabular}{ll}
\hline Sleep parameters & Definition \\
\hline Wake after sleep onset & $\begin{array}{l}\text { Amount of total wake time between } \\
\text { sleep-onset and final wake-up } \\
\text { (WASO) }\end{array}$ \\
Total sleep time (TST) & $\begin{array}{l}\text { period } \\
\text { Time period measured from light-off } \\
\text { to the beginning of sleep }\end{array}$ \\
Sleep onset latency (SOL) & Ratio of total sleep time to time in bed \\
Sleep efficiency (SE) & $\begin{array}{l}\text { An index used to assess severity of } \\
\text { sleep apnea based on total number of } \\
\text { complete cessations (apnea) and partial } \\
\text { obstructions (hypopnea) of breathing } \\
\text { occurring per hour of sleep } \\
\text { An index used to assess severity of } \\
\text { periodic limb movement disorder } \\
\text { based on total number of periodic limb } \\
\text { movements occurring per hour of sleep }\end{array}$ \\
Periodoc limb movement & \\
index (PLMI) &
\end{tabular}

measure frequently used to evaluate sleep disturbance among children with ADHD, was incongruent with the data from sleep logs, actigraphy, and polysomnography.

Objective measurements used to study sleep and ADHD include polysomnography and actigraphy. Polysomnography allows researchers to examine basic sleep parameters, sleep architecture (eg, total sleep time, wake after sleep onset, sleep onset latency, sleep efficiency), and pathological indices (eg, apnea-hypopnea index, periodic limb movement index). However, polysomnography requires subjects to sleep within laboratories, which may produce a sleep pattern that differs from their habitual sleep patterns. Prihodova et al ${ }^{16}$ pointed out that the "first-night effect" on sleep variables was more significant in the ADHD group than normal controls. Therefore, it might be necessary to record sleep for more than one night to ensure validity of the data. On the other hand, actigraphy assesses sleep patterns through the recording and analyses of activity patterns. It can provide sleep information, such as sleep onset, sleep offset, sleep onset latency, and wake after sleep onset. The biggest advantage of actigraphy is its capacity to collect data from more than 20 consecutive nights in natural settings. Nevertheless, it does not record pathophysiological indices that are necessary for the diagnosis of some sleep disorders. In addition to the disruption of night-time sleep, excessive daytime sleepiness is one of the major clinical characteristics in patients with sleep disorders. Hence, the multiple sleep latency test is also frequently used to measure daytime sleepiness in ADHD. ${ }^{16-18}$ The multiple sleep latency test assesses the physiologic sleep tendency by measuring the time it takes to fall asleep when one begins a nap in the absence of alerting factors, such as noise and light. ${ }^{19}$ 


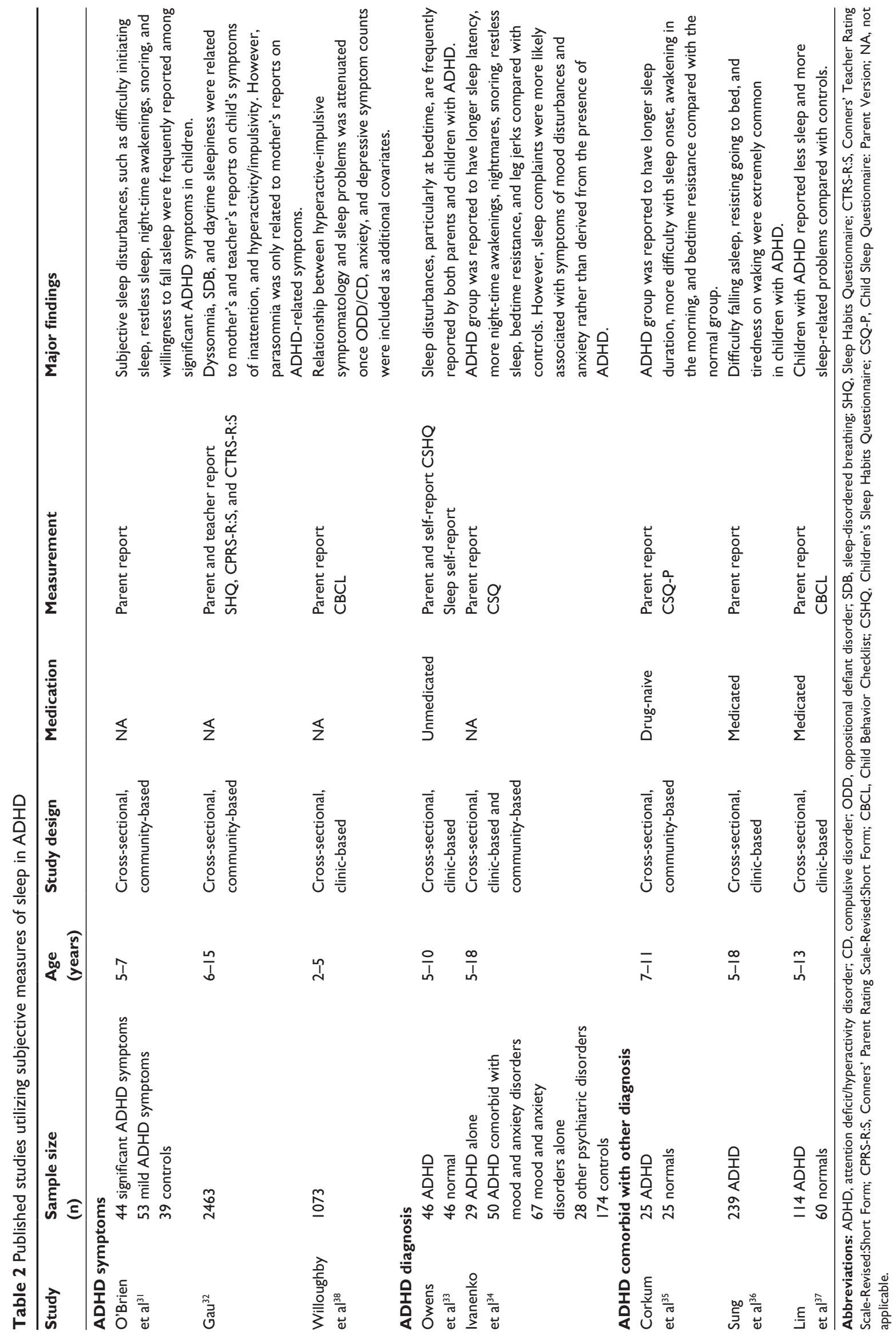




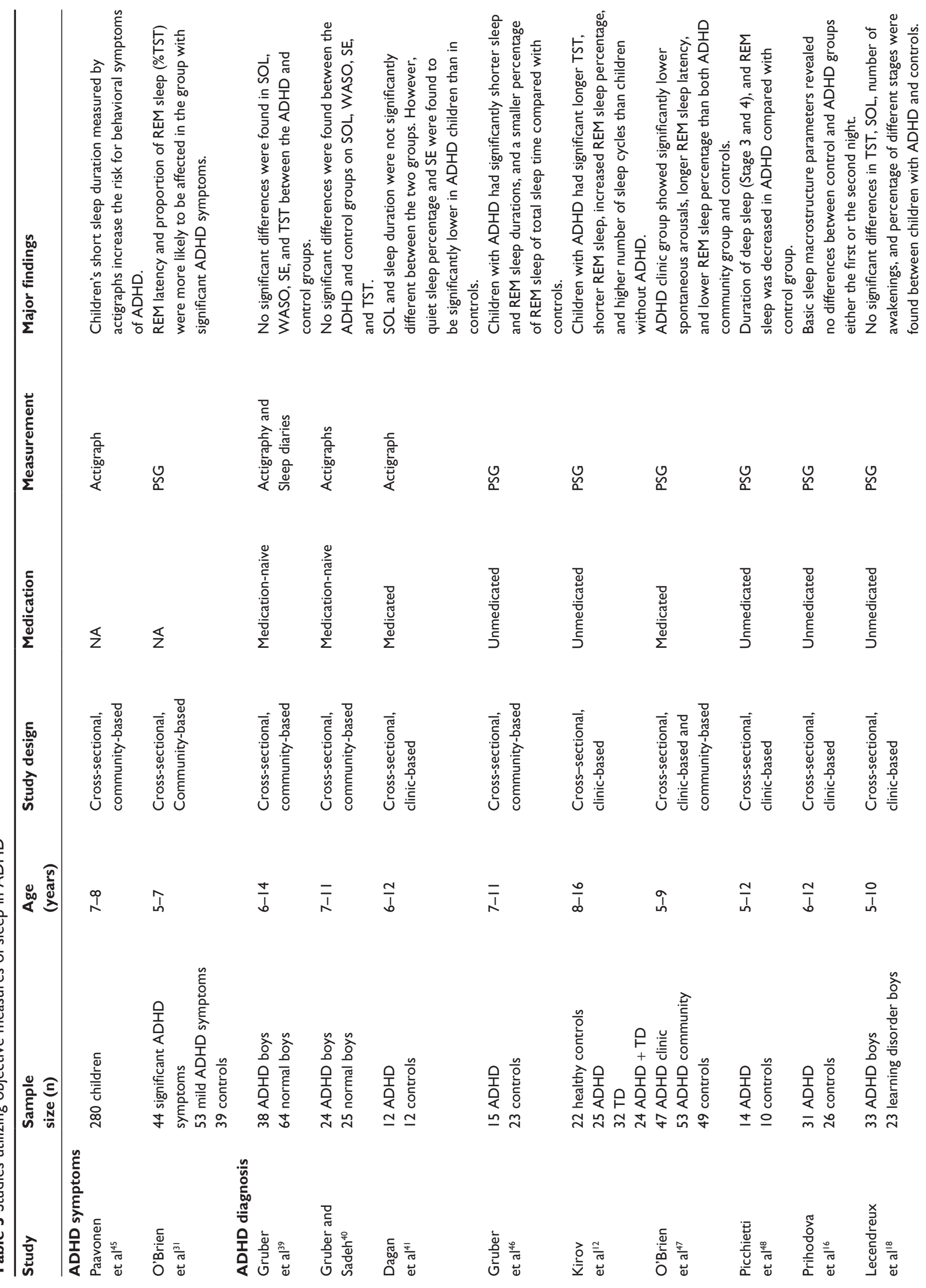




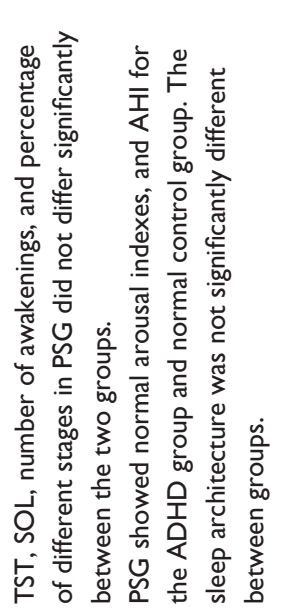

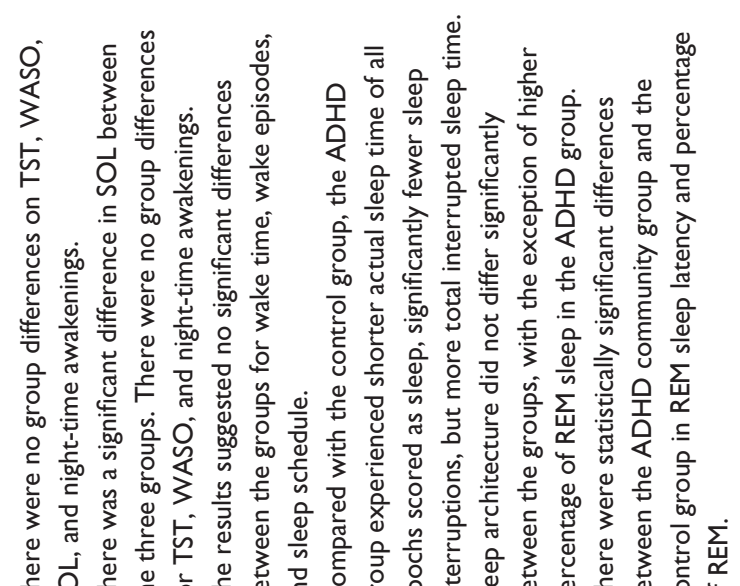

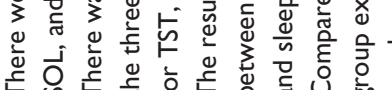

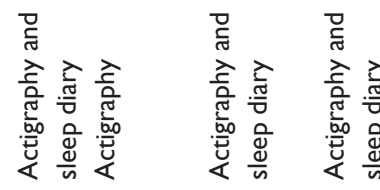

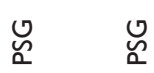

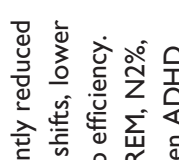

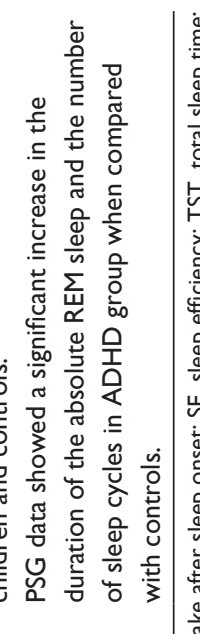

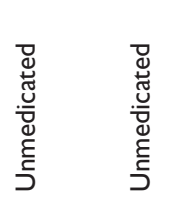

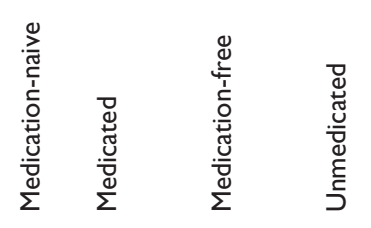

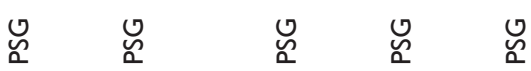

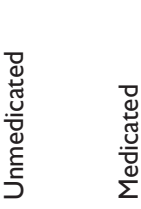

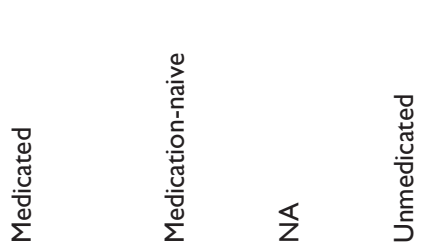

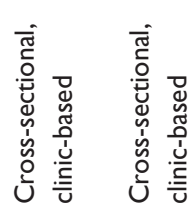
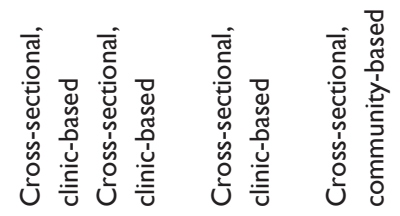

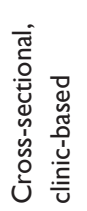

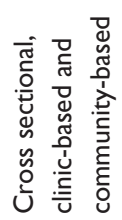

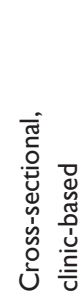

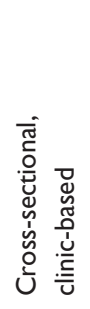

$\stackrel{ }{1} \frac{1}{1}$

$\overline{\frac{1}{1}} \frac{m}{1} \quad \frac{m}{1} \quad \frac{\pi}{b}$

i

$\frac{m}{b} \quad \bar{b} \quad \frac{\pi}{b}$

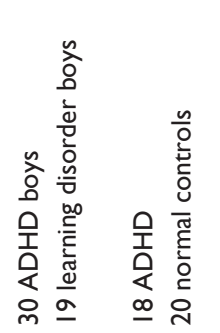

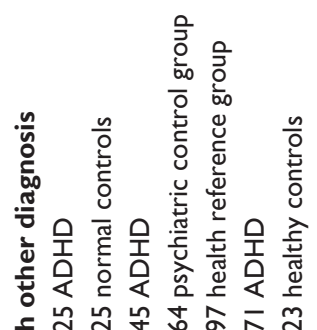

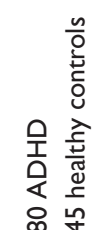

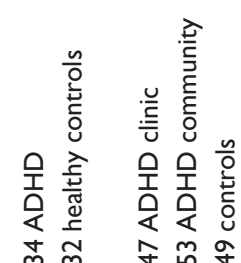

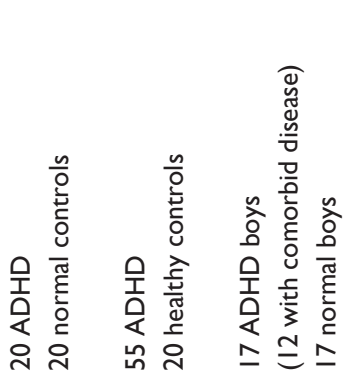
:

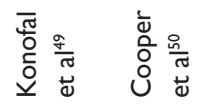

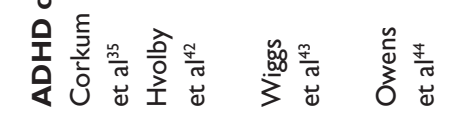

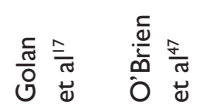

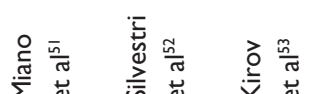

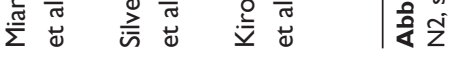


Table 4 Published studies investigating the relationship between ADHD and RLS in children

\begin{tabular}{|c|c|c|c|c|c|c|}
\hline Study & $\begin{array}{l}\text { Sample } \\
\text { size }(n)\end{array}$ & $\begin{array}{l}\text { Age } \\
\text { (years) }\end{array}$ & Study design & Medication & Measurement & Major findings \\
\hline \multicolumn{7}{|c|}{ ADHD symptoms } \\
\hline $\begin{array}{l}\text { Picchietti } \\
\text { and Stevens }{ }^{54}\end{array}$ & $18 \mathrm{RLS}$ & $8-24$ & $\begin{array}{l}\text { Cross-sectional, } \\
\text { clinic-based }\end{array}$ & NA & $\begin{array}{l}\mathrm{NIH} \text {-specific } \\
\text { pediatric criteria }\end{array}$ & $\begin{array}{l}\text { ADHD }(72 \%) \text { is a common } \\
\text { comorbidity of RLS. }\end{array}$ \\
\hline $\begin{array}{l}\text { Konofal } \\
\text { et } \mathrm{al}^{55}\end{array}$ & $\begin{array}{l}12 \mathrm{ADHD}+\mathrm{RLS} \\
10 \mathrm{ADHD} \\
10 \text { controls }\end{array}$ & $5-8$ & $\begin{array}{l}\text { Cross-sectional, } \\
\text { clinic-based }\end{array}$ & Unmedicated & $\begin{array}{l}\mathrm{NIH} \text {-specific } \\
\text { pediatric criteria } \\
\text { CPRS }\end{array}$ & $\begin{array}{l}\text { Children with ADHD and a positive } \\
\text { family of RLS are at risk of severe } \\
\text { ADHD symptoms. }\end{array}$ \\
\hline $\begin{array}{l}\text { Rajaram } \\
\text { et a }\left.\right|^{57}\end{array}$ & $\begin{array}{l}\text { II ADHD } \\
10 \text { controls }\end{array}$ & $5-12$ & $\begin{array}{l}\text { Cross-sectional, } \\
\text { clinic-based }\end{array}$ & NA & $\begin{array}{l}\text { Children and } \\
\text { parent's reports }\end{array}$ & $\begin{array}{l}\text { Some ADHD children with growing } \\
\text { pains may actually have RLS. }\end{array}$ \\
\hline $\begin{array}{l}\text { Kotagal and } \\
\text { Silber }\end{array}$ & 32 RLS & $<18$ & $\begin{array}{l}\text { Cross-sectional, } \\
\text { clinic-based }\end{array}$ & NA & PSG & $\begin{array}{l}\text { Inattentiveness was seen in } 8 \text { of } 32 \\
\text { subjects }(25 \%) \text {. }\end{array}$ \\
\hline $\begin{array}{l}\text { Chervin } \\
\text { et } \mathrm{al}^{58}\end{array}$ & 866 & $2-13$ & $\begin{array}{l}\text { Cross-sectional, } \\
\text { community-based }\end{array}$ & NA & $\begin{array}{l}\text { PSQ } \\
\text { CPRS }\end{array}$ & $\begin{array}{l}\text { Inattention and hyperactivity in general } \\
\text { pediatric patients associated with } \\
\text { symptoms of RLS. }\end{array}$ \\
\hline $\begin{array}{l}\text { Chervin } \\
\text { et } \mathrm{al}^{59}\end{array}$ & $\begin{array}{l}27 \text { ADHD } \\
43 \text { non-ADHD } \\
\text { psychiatry subjects } \\
73 \text { general pediatric } \\
\text { subjects }\end{array}$ & $2-18$ & $\begin{array}{l}\text { Cross-sectional, } \\
\text { clinic-based }\end{array}$ & NA & $\begin{array}{l}\text { PSQ } \\
\text { CPRS }\end{array}$ & $\begin{array}{l}\text { Complaint of restless legs and } \\
\text { a composite score for daytime } \\
\text { sleepiness showed some evidence } \\
\text { of an association with inattention } \\
\text { and hyperactivity. }\end{array}$ \\
\hline \multicolumn{7}{|c|}{ ADHD diagnosis } \\
\hline $\begin{array}{l}\text { Picchietti } \\
\text { et } \mathrm{al}^{48}\end{array}$ & $\begin{array}{l}\text { I } 4 \text { ADHD } \\
10 \text { control }\end{array}$ & $5-12$ & $\begin{array}{l}\text { Cross-sectional, } \\
\text { clinic-based }\end{array}$ & Unmedicated & PSG & $\begin{array}{l}\text { ADHD children's parents }(32 \%) \text { were } \\
\text { more likely to have RLS than the } \\
\text { control parents. }\end{array}$ \\
\hline
\end{tabular}

Abbreviations: ADHD, attention deficit/hyperactivity disorder; PSQ, Pediatric Sleep Questionnaire; CPRS, Conners' Parent Rating Scale; NA, not applicable; NIH, National Institutes of Health; PSG, polysomnography; RLS, restless legs syndrome.

In the previous review articles on sleep and ADHD, ${ }^{10,20}$ it was pointed out that there is a significant discrepancy between subjective and objective reports of sleep in children with ADHD. Owens ${ }^{21}$ and Konofal et a ${ }^{22}$ suggested that parents of children with behavioral disorders may be more likely to perceive and report higher levels of daytime and sleeprelated disruptive behaviors (bedtime struggles, difficulty with morning waking) in a sort of "negative halo effect". In addition, caregivers are more likely to be sensitive to the side effects of medication, and report sleep-related behavioral problems, such as prolonged sleep-onset latency.

\section{Impact of ADHD medication on sleep}

Stimulant medication is one of the most effective treatments attempted for the management of ADHD. ${ }^{23}$ It seems reasonable to assume that the central nervous system (CNS) stimulants prescribed to treat ADHD may adversely affect sleep due to their pharmacological character. For example, both statistically and clinically significant negative impacts have been reported in total sleep time ${ }^{24}$ and sleep onset latency ${ }^{24,25}$ in children with ADHD under stimulant medication compared with no-medication conditions. However, recent randomized, double-blind, placebo-controlled trials have demonstrated that CNS stimulants do not significantly increase sleep disturbances in ADHD. ${ }^{26,27}$ For example, one study examined sleep-related side effects of medications for children with ADHD and showed that there was a small increase in incidence of prolonged sleep onset latency and shortened total sleep time when a non-CNS stimulant (atomoxetine) was given compared with when a CNS stimulant (methylphenidate) was given. ${ }^{28}$ On the contrary, some beneficial effects were also noted in various subjective and objective measures of sleep. In addition, clonidine, a medication that is often prescribed to treat ADHD-related sleep disturbance, was found to alter the duration of a nonrapid eye movement (NREM)-rapid eye movement (REM) cycle. ${ }^{29}$

All in all, CNS stimulants may cause decreased total sleep time and prolonged sleep onset, and also improve sleep quality by consolidating sleep, decreasing nocturnal awakenings, and increasing the percentage of REM sleep. ${ }^{30}$ Furthermore, non-CNS stimulants also caused adverse effects on sleep but the effects were relatively mild.

\section{General sleep disturbances in ADHD}

The relationship between sleep disturbances and ADHD has been examined using different measures. In studies based on parents' reports (Table 2), children with ADHD symptoms were found to have more night waking, difficulty initiating sleep, 
Table 5 Published studies investigating the relationship between ADHD and PLMS in children

\begin{tabular}{|c|c|c|c|c|c|c|}
\hline Study & $\begin{array}{l}\text { Sample } \\
\text { size (n) }\end{array}$ & $\begin{array}{l}\text { Age } \\
\text { (years) }\end{array}$ & Study design & Medication & Measurement & Major findings \\
\hline \multicolumn{7}{|c|}{ ADHD symptoms } \\
\hline $\begin{array}{l}\text { Chervin } \\
\text { et al }\left.\right|^{58}\end{array}$ & 866 & $2-13$ & $\begin{array}{l}\text { Cross-sectional, } \\
\text { community-based }\end{array}$ & NA & $\begin{array}{l}\text { PSQ } \\
\text { CPRS }\end{array}$ & $\begin{array}{l}\text { Inattention and hyperactivity in } \\
\text { general pediatric patients were } \\
\text { associated with symptoms of PLMS. }\end{array}$ \\
\hline $\begin{array}{l}\text { Chervin and } \\
\text { Archbold }{ }^{74}\end{array}$ & 113 & $2-18$ & $\begin{array}{l}\text { Cross-sectional, } \\
\text { clinic-based }\end{array}$ & Medicated & $\begin{array}{l}\text { PSG } \\
\text { CPRS }\end{array}$ & $\begin{array}{l}\text { Rate of PLMS showed a linear } \\
\text { association with hyperactivity among } \\
\text { subjects with SDB, but no association } \\
\text { among those subjects without SDB. }\end{array}$ \\
\hline \multicolumn{7}{|c|}{ ADHD diagnosis } \\
\hline $\begin{array}{l}\text { Picchietti } \\
\text { et } \mathrm{al}^{48}\end{array}$ & $\begin{array}{l}\text { I4 ADHD } \\
10 \text { controls }\end{array}$ & $5-12$ & $\begin{array}{l}\text { Cross-sectional, } \\
\text { clinic-based }\end{array}$ & Unmedicated & PSG & $\begin{array}{l}\text { Prevalence of PLMS was higher in the } \\
\text { children with ADHD than in controls. }\end{array}$ \\
\hline \multicolumn{7}{|c|}{ ADHD comorbid with other diagnosis } \\
\hline $\begin{array}{l}\text { Silvestri } \\
\text { et a }\left.\right|^{52}\end{array}$ & $\begin{array}{l}55 \text { ADHD } \\
20 \text { healthy controls }\end{array}$ & $6-11$ & $\begin{array}{l}\text { Cross-sectional, } \\
\text { clinic-based }\end{array}$ & NA & $\begin{array}{l}\text { Nocturnal } \\
\text { video-PSG } \\
\text { International RLS } \\
\text { Rating Scale }\end{array}$ & $\begin{array}{l}\text { Significant correlations emerged } \\
\text { for International RLS Rating Scale } \\
\text { scoring, PLMS indices, hyperactivity, } \\
\text { opposition scores, and ADHD } \\
\text { subtypes. }\end{array}$ \\
\hline $\begin{array}{l}\text { Kirk and } \\
\text { Bohn }^{76}\end{array}$ & 591 & NA & $\begin{array}{l}\text { Cross-sectional, } \\
\text { clinic-based }\end{array}$ & NA & PSG & $\begin{array}{l}\text { Prevalence of PLMS in } 28 \text { children } \\
\text { with pre-existing diagnosis of ADHD } \\
\text { in our population was higher ( } 7.1 \%) \\
\text { than group prevalence }(5.6 \%) \text {. }\end{array}$ \\
\hline $\begin{array}{l}\text { Huang } \\
\text { et al }{ }^{77}\end{array}$ & $\begin{array}{l}88 \text { ADHD } \\
27 \text { healthy controls }\end{array}$ & $6-12$ & $\begin{array}{l}\text { Cross-sectional, } \\
\text { clinic-based }\end{array}$ & NA & PSG & $\begin{array}{l}\text { Nine }(10.2 \%) \text { of the ADHD group } \\
\text { had } \geq 5 \text { PLMS per hour, but none } \\
\text { in the control group. }\end{array}$ \\
\hline $\begin{array}{l}\text { Golan } \\
\text { et } \mathrm{al}^{17}\end{array}$ & $\begin{array}{l}34 \text { ADHD } \\
32 \text { healthy controls }\end{array}$ & $7-17$ & $\begin{array}{l}\text { Cross-sectional, } \\
\text { clinic-based }\end{array}$ & Unmedicated & PSG & $\begin{array}{l}\text { Five of the ADHD group had PLMS } \\
\text { during sleep (I5\%) versus none in the } \\
\text { control group. }\end{array}$ \\
\hline $\begin{array}{l}\text { Crabtree } \\
\text { et } \mathrm{al}^{75}\end{array}$ & $\begin{array}{l}40 \text { PLMD/ADHD } \\
50 \text { PLMD only } \\
52 \text { controls }\end{array}$ & $5-7$ & $\begin{array}{l}\text { Cross-sectional, } \\
\text { Community-based } \\
\text { and clinic-based } \\
\text { samples }\end{array}$ & Medicated & PSG & $\begin{array}{l}\text { Children with PLMD and ADHD } \\
\text { had a significantly greater number } \\
\text { of arousals associated with PLMS } \\
\text { than children with PLMD only. }\end{array}$ \\
\hline
\end{tabular}

Abbreviations: ADHD, attention deficit/hyperactivity disorder; PSQ, Pediatric Sleep Questionnaire; CPRS, Conners' Parent Rating Scale; PLMD, periodic limb movement disorder; RLS, restless legs syndrome; PLMS, periodic limb movements; SDB, sleep-disordered breathing; PSG, polysomnography.

bedtime resistance, and daytime sleepiness compared with normal control subjects. ${ }^{31,32}$ Children with ADHD were also reported to have significantly more bedtime resistance, longer sleep onset latency, shorter sleep duration, more parasomnias, more night waking, and higher level daytime sleepiness by parent's report. ${ }^{33,34}$ Children who have ADHD comorbid with other disorders were also reported to have longer sleep duration, more difficulty with sleep onset, more bedtime resistance, more difficulties awakening in the morning, and more nocturnal activities during sleep, ${ }^{35,36}$ but another study reported that they sleep less compared with normal subjects. ${ }^{37}$ However, one study reported that sleep complaints were more likely associated with symptoms of mood disturbance and anxiety rather than derived from the presence of ADHD. ${ }^{34}$ Symptoms of hyperactivity and impulsivity were also reported to have no significant association with parent-reported sleep problems once psychiatric comorbidity was controlled for in another study. ${ }^{38}$
In studies using actigraphy (Table 3), children with ADHD showed no significant difference in sleep onset latency and sleep efficiency compared with controls. ${ }^{39,40}$ However, sleep efficiency and the amount of "quiet" sleep was found to be significantly lower in medicated ADHD children than in controls. ${ }^{41}$ When looking at ADHD comorbid with other psychiatric diagnoses, results from actigraphy were less consistent. Most of these studies failed to find night-time awakenings that were clearly described in subjective reports..$^{35,42,43}$ Only one study indicated that children who have ADHD comorbid with other psychiatric diagnoses experience longer total interrupted sleep time, ${ }^{44}$ while another study showed that they experienced significantly longer sleep onset latency. ${ }^{42}$ In addition, another study indicated that healthy children with short nocturnal sleep duration as recorded by actigraphy were found to exhibit more symptoms of hyperactivity/impulsivity ${ }^{45}$ 
Table 6 Published studies investigating the relationship between ADHD and SDB in children

\begin{tabular}{|c|c|c|c|c|c|c|}
\hline$\overline{\text { Study }}$ & Sample size & Age & Study design & Medication & Measurement & Major findings \\
\hline \multicolumn{7}{|c|}{ ADHD symptoms } \\
\hline $\begin{array}{l}\text { Chervin } \\
\text { et a }\left.\right|^{81}\end{array}$ & 229 & $2-13$ & $\begin{array}{l}\text { Longitudinal study, } \\
\text { clinic-based }\end{array}$ & Medicated & $\begin{array}{l}\text { PSQ } \\
\text { CPRS }\end{array}$ & $\begin{array}{l}\text { Snoring and other symptoms of } \\
\text { SDB are strong risk factors for } \\
\text { future emergence or exacerbation } \\
\text { of hyperactive behavior. }\end{array}$ \\
\hline $\begin{array}{l}\text { Gottlieb } \\
\text { et } \mathrm{al}^{80}\end{array}$ & 3019 & 5 & $\begin{array}{l}\text { Cross-sectional, } \\
\text { community-based }\end{array}$ & NA & CPRS & $\begin{array}{l}\text { Children with SDB symptoms were } \\
\text { more likely to have hyperactivity, } \\
\text { inattention, and aggressiveness. }\end{array}$ \\
\hline $\begin{array}{l}\text { O'Brien } \\
\text { et a }\left.\right|^{31}\end{array}$ & $\begin{array}{l}44 \text { significant ADHD } \\
\text { symptoms } \\
53 \text { mild ADHD symptoms } \\
39 \text { controls }\end{array}$ & $5-7$ & $\begin{array}{l}\text { Cross-sectional, } \\
\text { community-based }\end{array}$ & NA & PSG & $\begin{array}{l}\text { SDB was highly prevalent in children } \\
\text { with mild ADHD symptoms but } \\
\text { not in those with significant ADHD } \\
\text { symptoms. }\end{array}$ \\
\hline $\begin{array}{l}\text { Chervin } \\
\text { et al }{ }^{79}\end{array}$ & 866 & $2-13$ & $\begin{array}{l}\text { Cross-sectional, } \\
\text { community-based }\end{array}$ & NA & $\begin{array}{l}\text { PSQ } \\
\text { CPRS }\end{array}$ & $\begin{array}{l}\text { Inattention and hyperactivity were } \\
\text { associated with snoring and other } \\
\text { symptoms of SDB. }\end{array}$ \\
\hline $\begin{array}{l}\text { Chervin and } \\
\text { Archbold }{ }^{74}\end{array}$ & 113 & $2-18$ & $\begin{array}{l}\text { Cross-sectional, } \\
\text { clinic-based }\end{array}$ & Medicated & $\begin{array}{l}\text { PSG } \\
\text { CPRS }\end{array}$ & $\begin{array}{l}\text { Hyperactivity showed no significant } \\
\text { associations with the rate of apneas } \\
\text { and hypopneas. }\end{array}$ \\
\hline \multicolumn{7}{|c|}{ ADHD comorbid with other diagnosis } \\
\hline $\begin{array}{l}\text { Huang } \\
\text { et } \mathrm{a}^{82}\end{array}$ & $\begin{array}{l}66 \mathrm{ADHD} \\
20 \text { healthy controls }\end{array}$ & $6-12$ & $\begin{array}{l}\text { Cross sectional, } \\
\text { clinic based }\end{array}$ & Medicated & PSG & $\begin{array}{l}\text { Inattention and hyperactivity } \\
\text { reduced after treating OSA by } \\
\text { adenotonsillectomy or treating } \\
\text { ADHD with stimulant }\end{array}$ \\
\hline $\begin{array}{l}\text { Huang } \\
\text { et } \mathrm{al}^{77}\end{array}$ & $\begin{array}{l}88 \text { ADHD } \\
27 \text { healthy controls }\end{array}$ & $6-12$ & $\begin{array}{l}\text { Cross-sectional, } \\
\text { clinic based }\end{array}$ & NA & PSG & $\begin{array}{l}\text { ADHD had a higher } \mathrm{AHI}(56.8 \% \\
\mathrm{AHI}>\mathrm{I}, 19.3 \% \mathrm{AHI}>5) \text { than } \\
\text { healthy controls }\end{array}$ \\
\hline $\begin{array}{l}\text { O'Brien } \\
\text { et al }{ }^{47}\end{array}$ & $\begin{array}{l}47 \text { ADHD clinic } \\
53 \text { ADHD community } \\
49 \text { controls }\end{array}$ & $5-7$ & $\begin{array}{l}\text { Cross-sectional, } \\
\text { clinic-based and } \\
\text { community-based }\end{array}$ & Medicated & PSG & $\begin{array}{l}\text { AHI and apnea index did not } \\
\text { differ in the } 3 \text { groups }\end{array}$ \\
\hline
\end{tabular}

Abbreviations: ADHD, attention deficit/hyperactivity disorder; AHI, apnea-hypopnea index; PSQ, Pediatric Sleep Questionnaire; CPRS, Conners' Parent Rating Scale; OSA, obstructive sleep apnea; PSG, polysomnography; SDB, sleep disordered breathing.

Many studies have tried to compare results of actigraphy with those from subjective reports by parents. Most of them found that subjective reports tended to overestimate sleep disturbances. ${ }^{42}$ It is also possible that the sleep disturbances that come to the attention of parents are not best detected by actigraphy. ${ }^{43}$ Results highlight the prominence of parentreported sleep disturbances in children with ADHD and the need for clinicians to screen routinely for the presence of sleep disorders and to assess detailed sleep physiology whenever sleep disturbances are indicated.

With regard to studies using polysomnography (Table 3), one study showed that nonmedicated children with ADHD were significantly different in their total sleep time compared with the control group. ${ }^{46}$ Three studies have reported inconsistent findings for REM duration. ${ }^{12,46,47}$ One study showed that the duration of stage 3 sleep was shorter in children with ADHD than in controls, ${ }^{48}$ while four studies found no significant differences in sleep variables. ${ }^{16,18,49,50}$
Compared with normal controls, children who have ADHD comorbid with other neurological and psychiatric disorders spent decreased time in bed, ${ }^{51}$ and had a shorter total sleep time, ${ }^{51,52}$ increased REM latency, ${ }^{47}$ higher arousal index, ${ }^{17,52}$ increased inconsistency in their REM sleep duration, ${ }^{17,47,51-53}$ and lower sleep efficiency ${ }^{52}$ on polysomnography. Thus, the hypothesis that sleep disturbances and specific changes in sleep macrostructure are connected with pure ADHD does not seem to be supported in this review of the literature.

Even though sleep difficulties might be common in young people with ADHD, results were not consistent across various measures of sleep. There might be many underlying factors which influence the relationship between ADHD and sleep problems. Therefore, correct identification of such factors may facilitate appropriate management of sleep disturbances in this population. The following section reviews the specific primary sleep disorders identified commonly in children with ADHD. 


\section{Sleep disorders in ADHD Restless legs syndrome}

Restless legs syndrome (RLS) is characterized by uncomfortable leg or body part sensations with an irresistible urge to move the legs. Recent attention focused on the association between ADHD and sleep disorders has led to a series of studies examining RLS in children with ADHD symptoms ${ }^{54-59}$ and with confirmed $\mathrm{ADHD}^{48}$ (Table 4). In a review of the literature, ${ }^{60}$ it was concluded that approximately $44 \%$ of patients with ADHD have RLS or RLS symptoms, and up to $26 \%$ of patients with RLS were found to have ADHD or ADHD symptoms. With the exclusion of "motor restlessness" as part of the diagnostic criteria for RLS in 2003, there is no longer any overlap of the diagnostic criteria for ADHD and RLS, ${ }^{61}$ and it has become easier to differentiate these distinct but symptomatically similar conditions.

Several mechanisms have been proposed to explain the association between ADHD (or ADHD symptoms) and RLS. ${ }^{60}$ In children, sleep disturbance may precede or overshadow the complaint of leg discomfort. ${ }^{56}$ The quality and quantity of a child's sleep is often diminished with RLS. This sleep deprivation resulting from RLS can cause moodiness, irritability, inattentiveness, fatigue, and hyperactivity. ${ }^{35,62,63}$ Therefore, RLS might lead to symptoms of ADHD through sleep disruption. Secondly, diurnal manifestations of RLS, hyperactivity and inattentiveness, might mimic ADHD symptoms or be misclassified as symptoms of hyperactivity. ${ }^{64} \mathrm{~A}$ third possibility is that RLS and ADHD might share a common pathology, such as a dopaminergic deficit. ${ }^{58}$ Such a possibility is supported by the previous open-label studies, showing that children with symptoms of RLS and ADHD could benefit from treatment with dopaminergic agents. ${ }^{65,66}$ However, the first double-blind study of a dopaminergic therapy found that L-dopa significantly improved symptoms of RLS and periodic limb movement disorder (PLMD) symptoms but not ADHD ${ }^{67}$ Because there were methodological limitations, including small sample size and inability to control for baseline differences in severity of ADHD symptoms, these results should be interpreted carefully and future studies are needed to address this issue further. The fourth explanation is that both ADHD and RLS are associated with iron deficiency. ${ }^{56,68,69}$ The findings described here are consistent with pathophysiological models of these disorders because iron is needed for dopamine synthesis. ${ }^{70}$ While dopaminergic agents are not approved for use in children with RLS, another possible implication of the association between RLS and ADHD symptoms concerns iron supplement treatment. Incidentally, iron supplementation has been reported to improve symptoms in children with ADHD with an irondeficient diet. ${ }^{71}$ Moreover, Konofal et $\mathrm{al}^{72}$ have pointed out that iron supplementation appeared to improve ADHD symptoms in children with low serum ferritin levels.

\section{Periodic limb movements}

Periodic limb movements (PLMS) is objectively defined as the presence of repetitive movements of the toes, feet, legs, thighs and arms that last $0.5-5.0$ seconds and occur at 5-90 second intervals during sleep. According to the reports, $80 \%$ of patients with RLS also have characteristic leg movements during sleep that meet the diagnostic criteria for PLMS ${ }^{73}$ Several investigators have reported excessive PLMS in association with ADHD symptoms ${ }^{58,74}$ (Table 5). The prevalence of PLMS in children diagnosed with ADHD is estimated to be as high as $7 \%-44 \%$, compared with a prevalence of only $1.2 \%-2.0 \%$ in pediatric populations at risk for sleep disorders. ${ }^{48,52,75,76}$ Moreover, Huang et $\mathrm{al}^{77}$ and Golan et $\mathrm{al}^{17}$ found on polysomnography that $10.2 \%-14.7 \%$ of children with ADHD comorbid with other diagnosis had PLMD compared with $0 \%$ of controls. Children with PLMD during sleep can have sleep fragmentation that can lead to increased risk of inattention and hyperactivity, which are two major symptoms of ADHD. Chervin et $a^{58}$ further reported a dose-dependent relationship between PLMS scores on the Pediatric Sleep Questionnaire and hyperactivity index on the Conners' Parent Rating Scale-Short Form. Crabtree et al ${ }^{75}$ also showed that children with PLMD and ADHD were more likely to have PLMS-related arousals than children with PLMD only. Thus, Crabtree et $\mathrm{al}^{75}$ postulated that the link between ADHD and PLMD may be mediated by sleep fragmentation associated with PLMS-induced arousals and the presence of reduced REM sleep.

In addition, ADHD, RLS, and PLMS are all associated with low iron stores. ${ }^{68,78}$ The finding of relative iron deficiency is consistent with pathophysiological models of these disorders because iron is needed for dopamine synthesis. Walters et $\mathrm{a}^{65}$ indicated the treatment of PLMD with dopaminergic agents in the absence of psychostimulant use resulted in marked improvements in PLMD and ADHD. Thus, both PLMS and ADHD have been shown to be related to dopamine production and metabolism.

\section{Sleep-disordered breathing}

Sleep-disordered breathing (SDB) in children includes a spectrum of disorders that vary in severity, ranging from obstructive sleep apnea at one end to primary snoring, ie, 
snoring without ventilator abnormalities. Several studies have demonstrated the association between symptoms of SDB and ADHD-related symptoms, ${ }^{31,47,77,79-81}$ but others have failed to show the association ${ }^{74,82}$ (Table 6). The inconsistent results were probably due to the difference in criteria used to diagnosis SDB (apnea-hypopnea index $<1$ or $<5$ ), as well as the aggravating effect of SDB on ADHD. Repeated episodes of nocturnal hypoxia in SDB comprise an important causal factor for neurobehavioral deficits. Sleep fragmentation resulting from frequent nocturnal arousals may also lead to daytime symptoms. ${ }^{21}$ Both neurobehavioral deficits and daytime symptoms might mimic or exacerbate the cardinal symptoms of ADHD.

Regarding treatment strategies in this population, both Huang et $\mathrm{al}^{82}$ and Dillon et $\mathrm{al}^{83}$ reported that behavioral morbidity in children with ADHD and SDB improved significantly more after adenotonsillectomy than after stimulant treatment. These results suggest that appropriate recognition and surgical treatment of underlying SDB in children with ADHD might prevent the need for long-term stimulant treatment. $^{82} \mathrm{~A}$ recent longitudinal study has shown that improvements were maintained 2.5 years after surgery. ${ }^{84}$

\section{Conclusion}

ADHD-related symptoms are frequently associated with sleep problems/disorders. In our literature review, sleep disturbances are less supported by objective sleep measurements in pure unmedicated ADHD. Therefore, evaluation of other psychiatric comorbidities and the side effects of medications is necessary when assessing the causes of their sleep complaints. Moreover, sleep disturbance is very complex, especially in ADHD children. It is critical for health providers caring for this population to identify correctly the exact abnormality in sleep disturbance within this group of children. Success in treating sleep disturbance in this population depends on accurate diagnosis of the exact sleep disturbance and its pathology. Our review shows that successful management of sleep problems/disorders results in considerable improvement in the level of daytime impairment. Future studies addressing the causal relationship between sleep problems and ADHD-related symptoms should take into account potential confounding variables and include better controls. In addition, research focused on surgical management (adenotonsillectomy) and iron supplementation should not only focus on reduction of the apnea-hypopnea index and the periodic limb movement index as the primary parameters of a successful treatment outcome, but also consider other measures of sleep disturbance.

\section{Disclosure}

The authors report no conflicts of interest in this work.

\section{References}

1. American Psychiatric Association. Diagnostic and Statistical Manual of Mental Disorders. 4th ed. Washington, DC: American Psychiatric Association; 1994.

2. Nair J, Ehimare U, Beitman BD, Nair SS, Lavin A. Clinical review: Evidence-based diagnosis and treatment of ADHD in children. Mo Med. 2006;103(6):617-621.

3. Barkley RA. Attention Deficit Hyperactivity Disorder: A Handbook for Diagnosis and Treatment. New York, NY: Guilford; 1990.

4. Brown RT, Freeman WS, Perrin JM, et al. Prevalence and assessment of attention-deficit/hyperactivity disorder in primary care settings. Pediatrics. 2001;107(3):E43. Available from: http://pediatrics. aappublications.org/content/107/3/e43.full.pdf + html. Accessed July 22, 2011.

5. Laufer MW, Denhoff E. Hyperkinetic behavior syndrome in children. J Pediatr. 1957;50(4):463-474.

6. American Psychiatric Association. Diagnostic and Statistical Manual of Mental Disorders. 3rd ed. Washington, DC: American Psychiatric Association; 1980.

7. American Psychiatric Association. Diagnostic and Statistical Manual of Mental Disorders. 3rd ed. Washington, DC: American Psychiatric Association; 1987.

8. Owens JA. The ADHD and sleep conundrum: A review. J Dev Behav Pediatr. 2005;26(4):312-322.

9. O'Brien LM, Gozal D. Sleep in children with attention deficit/hyperactivity disorder. Minerva Pediatr. 2004;56(6):585-601.

10. Cohen-Zion M, Ancoli-Israel S. Sleep in children with attention-deficit hyperactivity disorder (ADHD): A review of naturalistic and stimulant intervention studies. Sleep Med Rev. 2004;8(5):379-402.

11. Johnson JH, Alvarez HK, Loftis C. ADHD comorbidity and mimicry: Implications for assessment and treatment. In: Maria BL, editor. Current Management in Child Neurology. 3rd ed. Hamilton, Ontario: BC Decker; 2005.

12. Kirov R, Kinkelbur J, Banaschewski T, Rothenberger A. Sleep patterns in children with attention-deficit/hyperactivity disorder, tic disorder, and comorbidity. J Child Psychol Psychiatry. 2007;48(6):561-570.

13. Mayes SD, Calhoun SL, Bixler EO, et al. ADHD subtypes and comorbid anxiety, depression, and oppositional-defiant disorder: Differences in sleep problems. J Pediatr Psychol. 2009;34(3):328-337.

14. Alfano CA, Ginsburg GS, Kingery JN. Sleep-related problems among children and adolescents with anxiety disorders. $J$ Am Acad Child Adolesc Psychiatry. 2007;46(2):224-232.

15. Mick E, Biederman J, Jetton J, Faraone SV. Sleep disturbances associated with attention deficit hyperactivity disorder: The impact of psychiatric comorbidity and pharmacotherapy. J Child Adolesc Psychopharmacol. 2000;10(3):223-231.

16. Prihodova I, Paclt I, Kemlink D, Skibova J, Ptacek R, Nevsimalova S. Sleep disorders and daytime sleepiness in children with attention-deficit/ hyperactivity disorder: A two-night polysomnographic study with a multiple sleep latency test. Sleep Med. 2010;11(9):922-928.

17. Golan N, Shahar E, Ravid S, Pillar G. Sleep disorders and daytime sleepiness in children with attention-deficit/hyperactive disorder. Sleep. 2004;27(2):261-266.

18. Lecendreux M, Konofal E, Bouvard M, Falissard B, Mouren-Simeoni MC. Sleep and alertness in children with ADHD. J Child Psychol Psychiatry. 2000;41(6):803-812.

19. Carskadon MA, Dement WC, Mitler MM, Roth T, Westbrook PR, Keenan S. Guidelines for the multiple sleep latency test (MSLT): A standard measure of sleepiness. Sleep. 1986;9(4):519-524.

20. Corkum P, Tannock R, Moldofsky H. Sleep disturbances in children with attention-deficit/hyperactivity disorder. $J$ Am Acad Child Adolesc Psychiatry. 1998;37(6):637-646. 
21. Owens JA. Sleep disorders and attention-deficit/hyperactivity disorder. Curr Psychiatry Rep. 2008;10(5):439-444.

22. Konofal E, Lecendreux M, Cortese S. Sleep and ADHD. Sleep Med. 2010;11(7):652-658.

23. Clinical practice guideline: Treatment of the school-aged child with attention-deficit/hyperactivity disorder. Pediatrics. 2001;108(4): 1033-1044.

24. Corkum P, Panton R, Ironside S, Macpherson M, Williams T. Acute impact of immediate release methylphenidate administered three times a day on sleep in children with attention-deficit/hyperactivity disorder. J Pediatr Psychol. 2008;33(4):368-379.

25. Stein MA. Unravelling sleep problems in treated and untreated children with ADHD. J Child Adolesc Psychopharmacol. 1999;9(3):157-168.

26. Galland BC, Tripp EG, Taylor BJ. The sleep of children with attention deficit hyperactivity disorder on and off methylphenidate: A matched case-control study. J Sleep Res. 2010;19(2):366-373.

27. Faraone SV, Glatt SJ, Bukstein OG, Lopez FA, Arnold LE, Findling RL. Effects of once-daily oral and transdermal methylphenidate on sleep behavior of children with ADHD. J Atten Disord. 2009;12(4): 308-315.

28. Sangal RB, Owens J, Allen AJ, Sutton V, Schuh K, Kelsey D. Effects of atomoxetine and methylphenidate on sleep in children with ADHD. Sleep. 2006;29(12):1573-1585.

29. Miyazaki S, Uchida S, Mukai J, Nishihara K. Clonidine effects on allnight human sleep: Opposite action of low- and medium-dose clonidine on human NREM-REM sleep proportion. Psychiatry Clin Neurosci. 2004;58(2):138-144.

30. Huang YS, Tsai MH, Guilleminault C. Pharmacological treatment of ADHD and the short and long term effects on sleep. Curr Pharm Des. April 8, 2011. [Epub ahead of print].

31. O'Brien LM, Holbrook CR, Mervis CB, et al. Sleep and neurobehavioral characteristics of 5- to 7-year-old children with parentally reported symptoms of attention-deficit/hyperactivity disorder. Pediatrics. 2003;111(3):554-563.

32. Gau SS. Prevalence of sleep problems and their association with inattention/hyperactivity among children aged $6-15$ in Taiwan. J Sleep Res. 2006;15(4):403-414.

33. Owens JA, Maxim R, Nobile C, McGuinn M, Msall M. Parental and self-report of sleep in children with attention-deficit/hyperactivity disorder. Arch Pediatr Adolesc Med. 2000;154(6):549-555.

34. Ivanenko A, Crabtree VM, O'Brien LM, Gozal D. Sleep complaints and psychiatric symptoms in children evaluated at a pediatric mental health clinic. J Clin Sleep Med. 2006;2(1):42-48.

35. Corkum P, Tannock R, Moldofsky H, Hogg-Johnson S, Humphries T. Actigraphy and parental ratings of sleep in children with attention-deficit/hyperactivity disorder (ADHD). Sleep. 2001;24(3): 303-312.

36. Sung V, Hiscock H, Sciberras E, Efron D. Sleep problems in children with attention-deficit/hyperactivity disorder: Prevalence and the effect on the child and family. Arch Pediatr Adolesc Med. 2008;162(4):336-342.

37. Lim CG, Ooi YP, Fung DS, Mahendran R, Kaur A. Sleep disturbances in Singaporean children with attention deficit hyperactivity disorder Ann Acad Med Singapore. 2008;37(8):655-661.

38. Willoughby MT, Angold A, Egger HL. Parent-reported attentiondeficit/hyperactivity disorder symptomatology and sleep problems in a preschool-age pediatric clinic sample. J Am Acad Child Adolesc Psychiatry. 2008;47(9):1086-1094.

39. Gruber R, Sadeh A, Raviv A. Instability of sleep patterns in children with attention-deficit/hyperactivity disorder. $J$ Am Acad of Child Adolesc Psychiatry. 2000;39(4):495-501.

40. Gruber R, Sadeh A. Sleep and neurobehavioral functioning in boys with attention-deficit/hyperactivity disorder and no reported breathing problems. Sleep. 2004;27(2):267-273.

41. Dagan Y, Zeevi-Luria S, Sever Y, et al. Sleep quality in children with attention deficit hyperactivity disorder: An actigraphic study. Psychiatry Clin Neurosci. 1997;51(6):383-386.
42. Hvolby A, Jorgensen J, Bilenberg N. Actigraphic and parental reports of sleep difficulties in children with attention-deficit/hyperactivity disorder. Arch Pediatr Adolesc Med. 2008;162(4):323-329.

43. Wiggs L, Montgomery P, Stores G. Actigraphic and parent reports of sleep patterns and sleep disorders in children with subtypes of attentiondeficit hyperactivity disorder. Sleep. 2005;28(11):1437-1445.

44. Owens J, Sangal RB, Sutton VK, Bakken R, Allen AJ, Kelsey D. Subjective and objective measures of sleep in children with attention-deficit/ hyperactivity disorder. Sleep Med. 2009;10(4):446-456.

45. Paavonen EJ, Raikkonen K, Lahti J, et al. Short sleep duration and behavioral symptoms of attention-deficit/hyperactivity disorder in healthy 7- to 8-year-old children. Pediatrics. 2009;123(5):e857-e864. Available from: http://pediatrics.aappublications.org/content/123/5/ e857.full.pdf+html. Accessed July 22, 2011.

46. Gruber R, Xi T, Frenette S, Robert M, Vannasinh P, Carrier J. Sleep disturbances in prepubertal children with attention deficit hyperactivity disorder: A home polysomnography study. Sleep. 2009;32(3): 343-350.

47. O'Brien LM, Ivanenko A, Crabtree VM, et al. Sleep disturbances in children with attention deficit hyperactivity disorder. Pediatr Res. 2003;54(2):237-243.

48. Picchietti DL, Underwood DJ, Farris WA, et al. Further studies on periodic limb movement disorder and restless legs syndrome in children with attention-deficit hyperactivity disorder. Mov Disord. 1999; 14(6):1000-1007.

49. Konofal E, Lecendreux M, Bouvard MP, Mouren-Simeoni MC. High levels of nocturnal activity in children with attention-deficit hyperactivity disorder: A video analysis. Psychiatry Clin Neurosci. 2001; 55(2): $97-103$.

50. Cooper J, Tyler L, Wallace I, Burgess KR. No evidence of sleep apnea in children with attention deficit hyperactivity disorder. Clin Pediatr (Phila). 2004;43(7):609-614.

51. Miano S, Donfrancesco R, Bruni O, et al. NREM sleep instability is reduced in children with attention-deficit/hyperactivity disorder. Sleep . 2006;29(6):797-803.

52. Silvestri R, Gagliano A, Arico I, et al. Sleep disorders in children with Attention-Deficit/Hyperactivity Disorder (ADHD) recorded overnight by video-polysomnography. Sleep Med. 2009;10(10):1132-1138.

53. Kirov R, Kinkelbur J, Heipke S, et al. Is there a specific polysomnographic sleep pattern in children with attention deficit/hyperactivity disorder? J Sleep Res. 2004;13(1):87-93.

54. Picchietti DL, Stevens HE. Early manifestations of restless legs syndrome in childhood and adolescence. Sleep Med. 2008;9(7): 770-781.

55. Konofal E, Cortese S, Marchand M, Mouren MC, Arnulf I, Lecendreux M. Impact of restless legs syndrome and iron deficiency on attention-deficit/hyperactivity disorder in children. Sleep Med. 2007;8(7-8):711-715.

56. Kotagal S, Silber MH. Childhood-onset restless legs syndrome. Ann Neurol. 2004;56(6):803-807.

57. Rajaram SS, Walters AS, England SJ, Mehta D, Nizam F. Some children with growing pains may actually have restless legs syndrome. Sleep. 2004;27(4):767-773.

58. Chervin RD, Archbold KH, Dillon JE, et al. Associations between symptoms of inattention, hyperactivity, restless legs, and periodic leg movements. Sleep. 2002;25(2):213-218.

59. Chervin RD, Dillon JE, Bassetti C, Ganoczy DA, Pituch KJ. Symptoms of sleep disorders, inattention, and hyperactivity in children. Sleep. 1997;20(12):1185-1192.

60. Cortese S, Konofal E, Lecendreux M, et al. Restless legs syndrome and attention-deficit/hyperactivity disorder: A review of the literature. Sleep. 2005;28(8):1007-1013.

61. Allen RP, Picchietti D, Hening WA, Trenkwalder C, Walters AS, Montplaisi J. Restless legs syndrome: Diagnostic criteria, special considerations, and epidemiology. A report from the restless legs syndrome diagnosis and epidemiology workshop at the National Institutes of Health. Sleep Med. 2003;4(2):101-109. 
62. Kaplan BJ, McNicol J, Conte RA, Moghadam HK. Sleep disturbance in preschool-aged hyperactive and nonhyperactive children. Pediatrics. 1987;80(6):839-844.

63. Ring A, Stein D, Barak Y, et al. Sleep disturbances in children with attention-deficit/hyperactivity disorder: A comparative study with healthy siblings. J Learn Disabil. 1998;31(6):572-578.

64. Picchietti DL, England SJ, Walters AS, Willis K, Verrico T. Periodic limb movement disorder and restless legs syndrome in children with attention-deficit hyperactivity disorder. J Child Neurol. 1998; 13(12):588-594.

65. Walters AS, Mandelbaum DE, Lewin DS, Kugler S, England SJ, Miller M. Dopaminergic therapy in children with restless legs/periodic limb movements in sleep and ADHD. Dopaminergic Therapy Study Group. Pediatr Neurol. 2000;22(3):182-186.

66. Konofal E, Arnulf I, Lecendreux M, Mouren MC. Ropinirole in a child with attention-deficit hyperactivity disorder and restless legs syndrome. Pediatr Neurol. 2005;32(5):350-351.

67. England SJ, Picchietti DL, Couvadelli BV, et al. L-dopa improves restless legs syndrome and periodic limb movements in sleep but not attention-deficit-hyperactivity disorder in a double-blind trial in children. Sleep Med. 2011;12(5):471-477.

68. Konofal E, Lecendreux M, Arnulf I, Mouren MC. Iron deficiency in children with attention-deficit/hyperactivity disorder. Arch Pediatr Adolesc Med. 2004;158(12):1113-1115.

69. Kryger MH, Otake K, Foerster J. Low body stores of iron and restless legs syndrome: A correctable cause of insomnia in adolescents and teenagers. Sleep Med. 2002;3(2):127-132.

70. Earley CJ, Allen RP, Beard JL, Connor JR. Insight into the pathophysiology of restless legs syndrome. J Neurosci Res. 2000;62(5):623-628.

71. Sever Y, Ashkenazi A, Tyano S, Weizman A. Iron treatment in children with attention deficit hyperactivity disorder. A preliminary report. Neuropsychobiology. 1997;35(4):178-180.

72. Konofal E, Lecendreux M, Deron J, et al. Effects of iron supplementation on attention deficit hyperactivity disorder in children. Pediatr Neurol. 2008;38(1):20-26.
73. Chervin RD, Hedger KM. Clinical prediction of periodic leg movements during sleep in children. Sleep Med. 2001;2(6):501-510.

74. Chervin RD, Archbold KH. Hyperactivity and polysomnographic findings in children evaluated for sleep-disordered breathing. Sleep. 2001;24(3):313-320.

75. Crabtree VM, Ivanenko A, O’Brien LM, Gozal D. Periodic limb movement disorder of sleep in children. J Sleep Res. 2003;12(1):73-81.

76. Kirk VG, Bohn S. Periodic limb movements in children: Prevalence in a referred population. Sleep. 2004;27(2):313-315.

77. Huang YS, Chen NH, Li HY, Wu YY, Chao CC, Guilleminault C. Sleep disorders in Taiwanese children with attention deficit/hyperactivity disorder. J Sleep Res. 2004;13(3):269-277.

78. Earley CJ, Connor JR, Beard JL, Malecki EA, Epstein DK, Allen RP. Abnormalities in CSF concentrations of ferritin and transferrin in restless legs syndrome. Neurology. 2000;54(8):1698-1700.

79. Chervin RD, Archbold KH, Dillon JE, et al. Inattention, hyperactivity, and symptoms of sleep-disordered breathing. Pediatrics. 2002; 109(3):449-456.

80. Gottlieb DJ, Vezina RM, Chase C, et al. Symptoms of sleep-disordered breathing in 5-year-old children are associated with sleepiness and problem behaviors. Pediatrics. 2003;112(4):870-877.

81. Chervin RD, Ruzicka DL, Archbold KH, Dillon JE. Snoring predicts hyperactivity four years later. Sleep. 2005;28(7):885-890.

82. Huang YS, Guilleminault C, Li HY, Yang CM, Wu YY, Chen NH. Attention-deficit/hyperactivity disorder with obstructive sleep apnea: A treatment outcome study. Sleep Med. 2007;8(1):18-30.

83. Dillon JE, Blunden S, Ruzicka DL, et al. DSM-IV diagnoses and obstructive sleep apnea in children before and 1 year after adenotonsillectomy. J Am Acad Child Adolesc Psychiatry. 2007;46(11):1425-1436.

84. Wei JL, Bond J, Mayo MS, Smith HJ, Reese M, Weatherly RA. Improved behavior and sleep after adenotonsillectomy in children with sleep-disordered breathing: Long-term follow-up. Arch Otolaryngol Head Neck Surg. 2009;135(7):642-646.
Psychology Research and Behavior Management

\section{Publish your work in this journal}

Psychology Research and Behavior Management is an international, peerreviewed, open access journal focusing on the science of psychology and its application in behavior management to develop improved outcomes in the clinical, educational, sports and business arenas. Specific topics covered include: Neuroscience, memory \& decision making; Behavior

\section{Dovepress}

modification \& management; Clinical applications; Business \& sports performance management; Social and developmental studies; Animal studies. The manuscript management system is completely online and includes a quick and fair peer-review system. Visit http://www.dovepress. com/testimonials.php to read real quotes from published authors. 